\title{
Expression of ADP and TNF- $\alpha$ in patients with gestational diabetes mellitus and its relationship with pregnancy outcomes
}

\author{
WENGONG WEI and XIAOPING ZHANG \\ Department of Obstetrics and Gynecology, Qingpu Branch of Zhongshan Hospital \\ Affiliated to Fudan University, Shanghai 201700, P.R. China
}

Received October 22, 2019; Accepted April 16, 2020

DOI: $10.3892 /$ etm.2020.8952

\begin{abstract}
Expression of adiponectin (ADP) and tumor necrosis factor- $\alpha(\mathrm{TNF}-\alpha)$ in patients with gestational diabetes mellitus and its relationship with pregnancy outcomes was explored. A total of 78 patients with gestational diabetes mellitus admitted to Qingpu Branch of Zhongshan Hospital Affiliated to Fudan University from June 2017 to December 2018 were enrolled as an experimental group, and further 70 healthy pregnant women in physical examination during the same period were enrolled as a control group. Concentrations of ADP and TNF- $\alpha$ were determined and compared between the two groups. The patients were divided into high ADP expression group ( $\geq 6.84)$, low ADP expression group $(<6.84)$, high TNF- $\alpha$ expression group $(\geq 6.17)$ and low TNF- $\alpha$ expression group $(<6.17)$. Corresponding two groups were compared in terms of adverse pregnancy outcomes, respectively, and they were also compared with the control group. The clinical association between ADP and TNF- $\alpha$ was analyzed. TNF- $\alpha$ was highly expressed in the blood of patients with gestational diabetes mellitus, while ADP expression was low in the blood. The low expression of ADP was related to age, pregestational body mass index (BMI), gestational week, medical history and family history of diabetes mellitus (all $\mathrm{P}<0.05$ ), and the high expression of TNF- $\alpha$ was related to age, pregestational BMI, gestational week, medical history, amniotic fluid volume, abortion history, and family history of diabetes mellitus (all $\mathrm{P}<0.05$ ). The experimental group faced a higher risk of adverse pregnancy outcomes than the control group. Both ADP and TNF- $\alpha$ are abnormally expressed in the patients with gestational diabetes mellitus, and TNF- $\alpha$ is affected by more of the factors. The concentrations of ADP and TNF- $\alpha$ affect the pregnancy outcomes. It suggests that ADP and TNF- $\alpha$ can
\end{abstract}

Correspondence to: Dr Xiaoping Zhang, Department of Obstetrics and Gynecology, Qingpu Branch of Zhongshan Hospital Affiliated to Fudan University, 1158 Park East Road, Shanghai 201700, P.R. China

E-mail: p070ew@163.com; 745950546@qq.com

Key words: ADP, TNF- $\alpha$, gestational diabetes mellitus, disease state, pregnancy outcome be used as indexes for predicating pregnancy outcomes, and for judging the disease conditions and treatment of patients.

\section{Introduction}

Gestational diabetes mellitus (GDM) refers to glucose intolerance that occurs or is first recognized during pregnancy. It shows a morbidity of 5\% among pregnant women, and obese women face a higher risk of GDM during pregnancy (1). GDM is prone to lead to dystocia, neonatal hypoglycemia, hyperbilirubinemia, and GDM-related complications, making a certain impact on the health of pregnant women and fetuses (2). For example, women with GDM history face obviously high risks of type 2 diabetes mellitus and prediabetes after delivery (3). In addition, a study concluded that compared with pregnant women without gestational diabetes mellitus, those with this disease showed significantly increased stillbirth rate and perinatal mortality (4). At present, the treatment for GDM includes dietary adjustment, lifestyle changes, and drug therapy such as metformin and insulin (5). Once the blood sugar control fails to meet the standard, the incidence of complications such as premature delivery and neonatal hypoglycemia will greatly increase. Pregnancy is a special period, so many treatment methods are limited in different degrees during clinical application. In addition, there are also some controversies in the diagnosis and management of this diabetes (6). As the pathogenesis of GDM is still under investigation, the most effective treatment method is beyond the reach of clinical practice at present. However, many studies have revealed that insulin resistance and pancreatic $\beta$ cell secretion dysfunction are important pathological features of gestational diabetes mellitus. Insulin resistance refers to tissues that do not respond to insulin. Low-grade chronic inflammation related to obesity is a key factor of developing insulin resistance $(7,8)$, and obesity can increase the expression of certain inflammatory cytokines, activate multiple signal pathways, and participate in the pathogenesis of insulin resistance by interfering with insulin signal transmission (9). Tumor necrosis factor- $\alpha$ (TNF- $\alpha$ ) is a pro-inflammatory cytokine, which is generated by monocytes and macrophages, and participates in the regulation of many important cellular processes (10). A previous study has proven that the increase of TNF- $\alpha$ level leads to insulin resistance in adipose tissues and peripheral tissues (11). In addition, a variety of hormones secreted by adipocytes, such as adiponectin (ADP), are specifically expressed in adipose tissue, which directly 
causes the body sensitive to insulin. Therefore, ADP may play an important role in insulin resistance (12). This study explored the expression of serum ADP and TNF- $\alpha$ in GDM patients to provide reference for clinical predication and medication guidance of gestational diabetes mellitus.

\section{Patients and methods}

Clinical data. A total of 78 GDM patients admitted to Qingpu Branch of Zhongshan Hospital Affiliated to Fudan University (Shanghai, China) from June 2017 to December 2018 were enrolled as an experimental group, and further 70 healthy pregnant women in physical examination during the same period were enrolled as a control group. This study was approved by the Ethics Committee of Qingpu Branch of Zhongshan Hospital Affiliated to Fudan University, and signed informed consents were obtained from the patients and/or guardians.

Inclusion and exclusion criteria. The inclusion criteria of the experimental group were as follows: Patients first admitted to Qingpu Branch of Zhongshan Hospital Affiliated to Fudan University, patients with GDM based on clinical examination, and patients who received treatment including oral antiglycemics, injection of insulin and dietary intervention according to the conditions of patients in Qingpu Branch of Zhongshan Hospital Affiliated to Fudan University after diagnosis. The blood glucose was controlled between $3.3 \mathrm{mmol} / \mathrm{l}$ and $5.3 \mathrm{mmol} / 1$ before meal, and between $3.3 \mathrm{mmol} / \mathrm{l}$ and $6.7 \mathrm{mmol} / \mathrm{l} 2 \mathrm{~h}$ after meal. When the blood glucose level declined, the amount of medicine was reduced as appropriate. The exclusion criteria were as follows: i) Patients with diabetes mellitus before pregnancy; ii) patients with comorbid cardiovascular diseases, hepatic or kidney function obstacle; iii) patients with a history of drug allergy; iv) patients with mental disease and unable to cooperate; v) patients ending pregnancy in the middle of the pregnancy course; vi) patients transferred to another hospital during the study; vii) patients without required pregnancy examination data.

Methods. Fasting venous blood $(2 \mathrm{ml})$ was sampled from each subject of the two groups, and the expression of ADP and TNF- $\alpha$ in the blood samples was determined using the enzyme-linked immunosorbent assay (ELISA). ADP test kits were purchased from Shanghai XinYu Biological Technology Co., Ltd. (item no. xy-A10927), and TNF- $\alpha$ kit was purchased from Shanghai Jingkang Bioengineering Co., Ltd. (item no. JKSJ-1857). All operations were carried out strictly in accordance with the kit instructions.

Observation indexes. The expression of ADP and TNF- $\alpha$ in the blood samples of the experimental group was compared with that in the blood samples of the control group during pregnancy and after pregnancy.

Statistical analysis. SPSS 24.0 was employed for statistical analysis. Enumeration data were expressed as rate, Chi-square test was used for comparison between groups; measurement data were expressed as mean $\pm \mathrm{SD}$, t-test was used for comparison between groups; diagnostic value was analyzed by ROC curve. $\mathrm{P}<0.05$ indicates a significant difference.

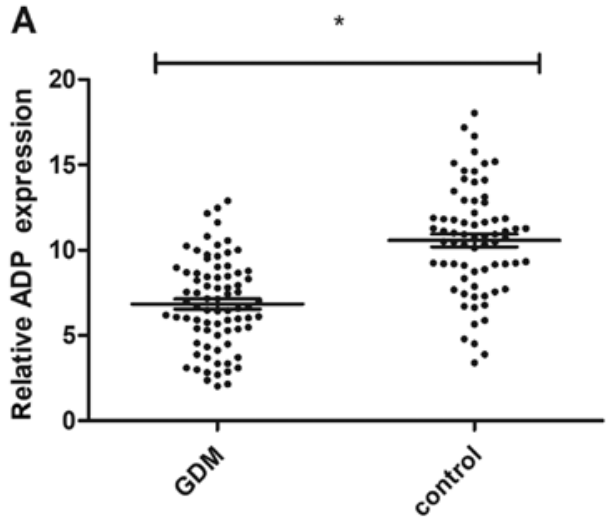

B

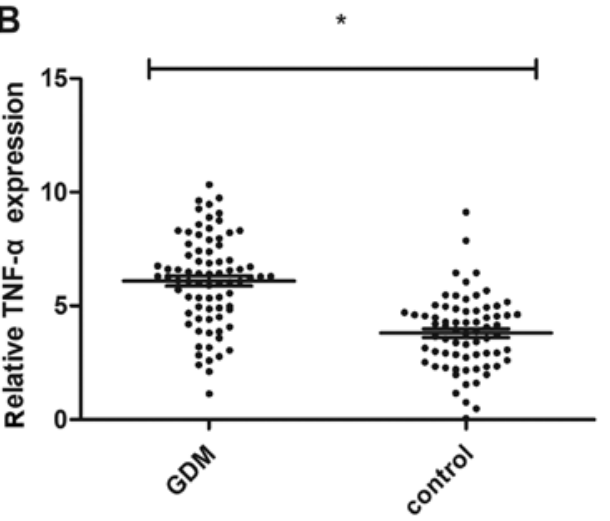

Figure 1. Difference of serum ADP and TNF- $\alpha$ expression levels between pregnant women with GDM and normal pregnant women. (A) The expression level of serum ADP in the experimental group was significantly lower than that in the control group before treatment; (B) The expression level of TNF- $\alpha$ in the experimental group was significantly higher than that in the control group. ${ }^{*} \mathrm{P}<0.01$. ADP, adiponectin; TNF- $\alpha$, tumor necrosis factor- $\alpha$; GDM, gestational diabetes mellitus.

\section{Results}

General materials. Comparison between the experimental group and the control group in clinical data revealed that there were no significant differences in age, pregestational body mass index (BMI), gestational week, average weekly exercise time, amniotic fluid volume, medical history (impaired glucose tolerance and polycystic ovary syndrome), family history of diabetes mellitus, abortion history, dietary habit, place of residence, and ethnicity (all $\mathrm{P}>0.05$ ), which proved the comparability between the two groups (Table I).

Determination of serum ADP and TNF- $\alpha$ expression in the experimental group and the control group. Blood was sampled from 78 pregnant women with GDM and 70 healthy pregnant women before treatment, and the expression levels of ADP and TNF- $\alpha$ in the blood were determined using the ELISA. The expression of ADP in pregnant women with GDM was significantly lower than that in healthy pregnant women $(6.84 \pm 2.72$ vs. $10.21 \pm 3.45 \mathrm{mg} / 1, \mathrm{P}<0.01)$, while the expression of TNF- $\alpha$ in the pregnant women with GDM was significantly higher than that in the healthy pregnant women (6.17 \pm 2.06 vs. $3.62 \pm 1.54 \mathrm{ng} / \mathrm{l}, \mathrm{P}<0.01$ ) (Fig. 1).

Changes of $A D P$ and TNF- $\alpha$ in the experimental group after treatment. After treatment, the expression levels of ADP and 
Table I. Comparison between the two groups in clinical data [mean $\pm \mathrm{SD}, \mathrm{n}(\%)$ ].

\begin{tabular}{|c|c|c|c|c|}
\hline $\begin{array}{l}\text { Clinicopathological } \\
\text { characteristics }\end{array}$ & $\begin{array}{l}\text { Experimental } \\
\text { group }(n=78)\end{array}$ & $\begin{array}{c}\text { Control } \\
\text { group }(\mathrm{n}=70)\end{array}$ & $\operatorname{tor} \chi^{2}$ & P-value \\
\hline Age (years) & $27.13 \pm 4.81$ & $26.94 \pm 4.67$ & 0.243 & 0.808 \\
\hline Pregestational BMI $\left(\mathrm{kg} / \mathrm{m}^{2}\right)$ & $23.52 \pm 2.44$ & $22.86 \pm 3.17$ & 1.427 & 0.156 \\
\hline Gestational week & $20.39 \pm 3.65$ & $20.31 \pm 3.96$ & 0.128 & 0.898 \\
\hline Average weekly exercise time (h) & $9.37 \pm 2.58$ & $9.62 \pm 2.74$ & 0.572 & 0.569 \\
\hline $\begin{array}{l}\text { Amniotic fluid volume, } \mathrm{ml} \\
\geq 2,000 \\
<2,000\end{array}$ & $\begin{array}{l}14(17.95) \\
64(82.05)\end{array}$ & $\begin{array}{r}8(11.43) \\
62(88.57)\end{array}$ & 1.239 & 0.266 \\
\hline $\begin{array}{l}\text { Medical history } \\
\text { Yes } \\
\text { No }\end{array}$ & $\begin{array}{l}13(16.67) \\
65(83.33)\end{array}$ & $\begin{array}{c}6(8.57) \\
64(91.43)\end{array}$ & 2.161 & 0.142 \\
\hline $\begin{array}{l}\text { Family history of diabetes mellitus } \\
\text { Yes } \\
\text { None }\end{array}$ & $\begin{array}{l}31(39.74) \\
47(60.26)\end{array}$ & $\begin{array}{l}18(25.71) \\
52(74.29)\end{array}$ & 3.279 & 0.070 \\
\hline $\begin{array}{l}\text { Abortion history } \\
\text { Yes } \\
\text { None }\end{array}$ & $\begin{array}{l}28(35.90) \\
50(64.10)\end{array}$ & $\begin{array}{l}17(24.29) \\
53(75.71)\end{array}$ & 2.351 & 0.125 \\
\hline $\begin{array}{l}\text { Dietary habit } \\
\text { Light } \\
\text { Spicy }\end{array}$ & $\begin{array}{l}52(66.67) \\
26(33.33)\end{array}$ & $\begin{array}{l}43(61.43) \\
27(38.57)\end{array}$ & 0.440 & 0.507 \\
\hline $\begin{array}{l}\text { Place of residence } \\
\text { Rural area } \\
\text { Urban area }\end{array}$ & $\begin{array}{l}31(39.74) \\
47(60.26)\end{array}$ & $\begin{array}{l}29(41.43) \\
41(58.57)\end{array}$ & 0.043 & 0.835 \\
\hline $\begin{array}{l}\text { Ethnicity } \\
\text { Han } \\
\text { Minority }\end{array}$ & $\begin{array}{l}62(79.49) \\
16(20.51)\end{array}$ & $\begin{array}{l}50(71.43) \\
20(28.57)\end{array}$ & 1.302 & 0.254 \\
\hline
\end{tabular}

Table II. Changes of ADP and TNF- $\alpha$ in the experimental group after delivery.

\begin{tabular}{lcc}
\hline Index & ADP $(\mathrm{mg} / \mathrm{l})$ & $\mathrm{TNF}-\alpha(\mathrm{ng} / \mathrm{l})$ \\
\hline Before treatment & $6.84 \pm 2.72$ & $6.17 \pm 2.06$ \\
One week after delivery & $9.39 \pm 2.15$ & $3.52 \pm 1.47$ \\
t value & 6.496 & 9.248 \\
P-value & $<0.001$ & $<0.001$
\end{tabular}

ADP, adiponectin; TNF- $\alpha$, tumor necrosis factor- $\alpha$.

TNF- $\alpha$ in the experimental group one week after delivery were $9.39 \pm 2.15 \mathrm{mg} / \mathrm{l}$ and $3.52 \pm 1.47 \mathrm{ng} / \mathrm{l}$, respectively, which was significantly lower than those before treatment (both $\mathrm{P}<0.01$ ) (Table II).

Association of serum ADP and TNF- $\alpha$ levels and pregnancy outcomes. The serum ADP and TNF- $\alpha$ levels were related to fetal distress, macrosomia, fetal malformation, and reproductive tract infection. The experimental group was divided into high ADP expression group ( $\geq 6.84)$, low ADP expression group $(<6.84)$, high TNF- $\alpha$ expression group $(\geq 6.17)$ and low TNF- $\alpha$ expression group $(<6.17)$ according to the mean ADP concentration and mean TNF- $\alpha$ concentration. Analysis of Table III shows that the rate of adverse pregnancy outcomes in the low ADP expression group was higher than that in the high ADP expression group, and the rates in both groups were higher than that in the control group (both $\mathrm{P}<0.05$ ). Analysis of Table IV shows that the rate of adverse pregnancy outcomes in the high TNF- $\alpha$ expression group was higher than that in the low TNF- $\alpha$ expression group, and the rates in both groups were higher than that in the control group (both $\mathrm{P}<0.05$ ).

Prediction of GDM by ADP and TNF- $\alpha$. The expression levels of serum ADP and TNF- $\alpha$ in the GDM patients were determined using ELISA, and ROC curves were drawn. Analysis of the curves showed that the area under the curve (AUC) of ADP was 0.821 , and the sensitivity, specificity, critical value, and 95\% CI were 72.86, 82.05, 9.09, and 71.72-89.83\%, respectively; the AUC of TNF- $\alpha$ was 0.815 , and the sensitivity, specificity, critical value, and $95 \%$ CI were $87.14,69.23,5.32$ and $57.76-79.19 \%$, respectively (Figs. 2 and 3).

Association of ADP and TNF- $\alpha$ concentrations with clinical pathology in the experimental group. Analysis revealed that 
Table III. Comparison of pregnancy outcomes between two groups with different ADP expression [mean \pm SD, $\mathrm{n}(\%)]$.

\begin{tabular}{lccccccc}
\hline & $\begin{array}{c}\text { Concentration } \\
(\mathrm{mg} / \mathrm{l})\end{array}$ & $\begin{array}{c}\text { No. of } \\
\text { patients }\end{array}$ & $\begin{array}{c}\text { Fetal } \\
\text { distress }\end{array}$ & Macrosomia & $\begin{array}{c}\text { Fetal } \\
\text { malformation }\end{array}$ & $\begin{array}{c}\text { Reproductive } \\
\text { tract } \\
\text { infection }\end{array}$ & $\begin{array}{c}\text { Adverse } \\
\text { pregnancy } \\
\text { outcomes }\end{array}$ \\
\hline High expression group & $9.51 \pm 2.17$ & 36 & $4(11.11)$ & $3(8.33)$ & $2(5.56)$ & $5(13.89)$ & $14(38.89)^{\mathrm{b}}$ \\
Low expression group & $8.43 \pm 2.44$ & 42 & $7(16.67)$ & $9(21.43)$ & $4(9.52)$ & $10(23.81)$ & $30(71.43)^{\mathrm{a}, \mathrm{b}}$ \\
Control group & & 70 & $2(2.86)$ & $2(2.86)$ & $0(0.00)$ & $5(7.14)$ & $9(12.86)$ \\
$\chi^{2}$ value & & & & & & & 39.370 \\
P-value & & & & & & & $<0.01$ \\
\hline
\end{tabular}

${ }^{\text {a }}<0.05$, compared with the high expression group; ${ }^{\text {}} \mathrm{P}<0.05$, compared with the control group. ADP, adiponectin.

Table IV. Comparison of pregnancy outcomes between two groups with different TNF- $\alpha$ expression [mean \pm SD, $\mathrm{n}(\%)]$.

\begin{tabular}{lccccccc}
\hline & $\begin{array}{c}\text { Concentration } \\
(\mathrm{ng} / \mathrm{l})\end{array}$ & $\begin{array}{c}\text { No. of } \\
\text { cases }\end{array}$ & $\begin{array}{c}\text { Fetal } \\
\text { distress }\end{array}$ & Macrosomia & $\begin{array}{c}\text { Fetal } \\
\text { malformation }\end{array}$ & $\begin{array}{c}\text { Reproductive } \\
\text { tract } \\
\text { infection }\end{array}$ & $\begin{array}{c}\text { Adverse } \\
\text { pregnancy } \\
\text { outcomes }\end{array}$ \\
\hline High expression group & $5.97 \pm 1.61$ & 43 & $8(18.60)$ & $8(18.60)$ & $4(9.30)$ & $12(27.91)$ & $32(74.41)^{\mathrm{a}, \mathrm{b}}$ \\
Low expression group & $4.36 \pm 1.52$ & 35 & $4(11.43)$ & $5(14.29)$ & $2(5.71)$ & $7(20.00)$ & $18(51.43)^{\mathrm{b}}$ \\
Control group & & 70 & $2(2.86)$ & $2(2.86)$ & $0(0.00)$ & $5(7.14)$ & $9(12.86)$ \\
$\chi^{2}$ value & & & & & & & 44.670 \\
P-value & & & & & & $<0.01$ \\
\hline
\end{tabular}

${ }^{\mathrm{a}} \mathrm{P}<0.05$, compared with the low expression group; ${ }^{\mathrm{b}} \mathrm{P}<0.05$, compared with the control group. TNF- $\alpha$, tumor necrosis factor- $\alpha$.

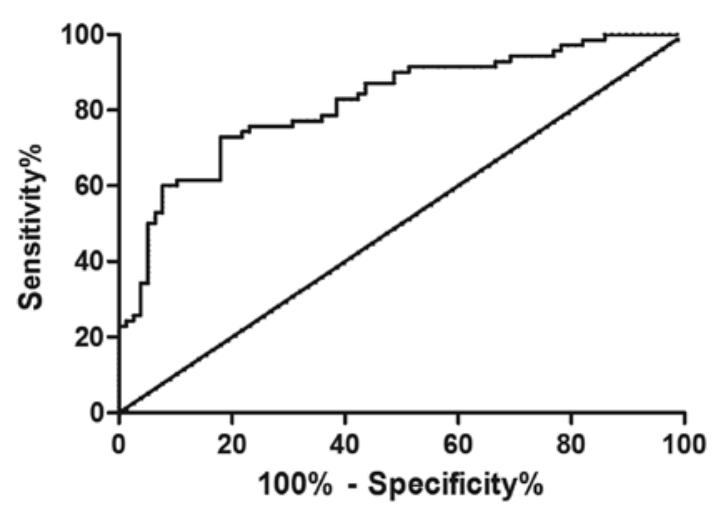

Figure 2. Analysis of ROC curve of ADP in diagnosis of gestational diabetes. When the cutoff value is 9.09 , ADP has a high sensitivity and specificity in the diagnosis of gestational diabetes. ADP, adiponectin.

in the experimental group, ADP was not significantly correlated with amniotic fluid volume, abortion history, ethnicity, or dietary habit (all $\mathrm{P}>0.05$ ), but significantly and negatively correlated with age, pregestational BMI, gestational week, medical history, and family history of diabetes mellitus (all $\mathrm{P}<0.05)$. In addition, TNF- $\alpha$ was not significantly correlated with ethnicity or dietary habit (both $\mathrm{P}>0.05$ ), but was significantly correlated with age, pregestational BMI, gestational week amniotic fluid volume, medical history, abortion history, and family history of diabetes mellitus (all $\mathrm{P}<0.05$ ). Details are shown in Tables V and VI.

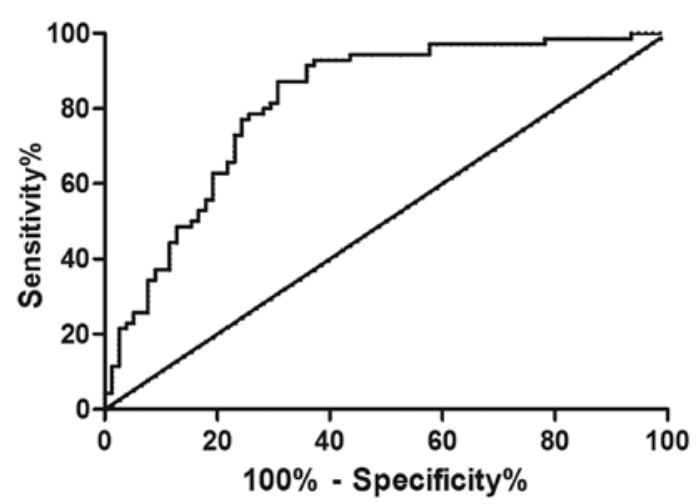

Figure 3. Analysis of ROC curve of TNF- $\alpha$ in diagnosis of gestational diabetes. When the cutoff value is 5.32 , TNF- $\alpha$ has a high sensitivity and specificity in the diagnosis of gestational diabetes. TNF- $\alpha$, tumor necrosis factor- $\alpha$.

\section{Discussion}

GDM refers to glucose intolerance that occurs or is first recognized during pregnancy (13). It can be diagnosed when the patient has no diabetes before pregnancy and fasting blood glucose $\geq 5.1 \mathrm{mmol} / 1$, and occur in second and third trimester. Overweight and obesity increase the risk of disease (14). GDM is a risk factor for type 2 diabetes mellitus. A study has shown that women with GDM history face a higher risk of suffering from type 2 diabetes mellitus than healthy pregnancy women (15). Moreover, women with GDM face a higher 
Table V. Association of ADP with clinical pathology in the experimental group .

\begin{tabular}{|c|c|c|c|c|}
\hline Clinicopathological characteristics & No. & Concentration (mg/l) & $\mathrm{t}$ & P-value \\
\hline Age, weeks & & & 2.243 & 0.029 \\
\hline$>28$ & 43 & $5.46 \pm 2.34$ & & \\
\hline$\leq 28$ & 35 & $6.77 \pm 2.82$ & & \\
\hline Pregestational BMI, $\mathrm{kg} / \mathrm{m}^{2}$ & & & 2.558 & 0.013 \\
\hline$\leq 22.15$ & 49 & $6.42 \pm 2.05$ & & \\
\hline$>22.15$ & 29 & $5.23 \pm 1.87$ & & \\
\hline Gestational week & & & 2.111 & 0.038 \\
\hline$\leq 20.23$ & 30 & $6.19 \pm 1.87$ & & \\
\hline$>20.23$ & 48 & $5.31 \pm 1.74$ & & \\
\hline Amniotic fluid volume, $\mathrm{ml}$ & & & 0.204 & 0.839 \\
\hline$\geq 2,000$ & 14 & $6.28 \pm 2.56$ & & \\
\hline$<2,000$ & 64 & $6.41 \pm 2.07$ & & \\
\hline Abortion history & & & 0.444 & 0.658 \\
\hline Yes & 28 & $6.27 \pm 2.08$ & & \\
\hline None & 50 & $6.49 \pm 2.11$ & & \\
\hline Medical history & & & 2.412 & 0.018 \\
\hline Yes & 13 & $5.67 \pm 1.33$ & & \\
\hline No & 65 & $6.89 \pm 1.72$ & & \\
\hline Family history of diabetes mellitus & & & 2.120 & 0.037 \\
\hline Yes & 31 & $5.73 \pm 1.47$ & & \\
\hline None & 47 & $6.54 \pm 1.76$ & & \\
\hline Ethnicity & & & 0.363 & 0.718 \\
\hline Han & 62 & $6.28 \pm 2.31$ & & \\
\hline Minority & 16 & $6.52 \pm 2.54$ & & \\
\hline Dietary habit & & & 0.272 & 0.787 \\
\hline Light & 52 & $6.32 \pm 2.13$ & & \\
\hline Spicy & 26 & $6.47 \pm 2.61$ & & \\
\hline
\end{tabular}

ADP, adiponectin.

risk of adverse pregnancy outcomes such as macrosomia, dystocia, and abortion, of which macrosomia is the result of maternal hyperglycemia accelerating fetal growth (16). Moreover, women with GDM also face a higher risk of suffering from cardiovascular diseases after delivery $(17,18)$. Therefore, GDM is seriously endangering the health of pregnant women and infants, and is likely to play an important role in the global diabetes epidemic (19). At present, GDM is mainly treated by lifestyle intervention, oral hypoglycemic agents, and insulin injection $(20,21)$, but there are still adverse reactions such as neonatal hypoglycemia and preeclampsia due to diseases (22).

A study concluded that insulin resistance is an important pathophysiological factor of GDM (23). With the deepening of research, increasing number of researchers have pointed out that many factors including interleukin and adipocyte factors are involved in the occurrence and progression of GDM (7). ADP is an endogenous bioactive polypeptide or protein secreted by adipocytes, and an insulin-sensitizing hormone, which is closely related to insulin resistance, obesity, and cardiovascular diseases (24). TNF includes TNF- $\beta$ secreted by activated
T lymphocytes and TNF- $\alpha$ secreted by monocyte-macrophage cells, of which TNF- $\alpha$ is a pro-inflammatory cell and is considered to be one of the important factors of insulin resistance in diabetes mellitus (25). A previous study revealed that the overall risk of type 2 diabetes mellitus was closely related to TNF- $\alpha$ and low adiponectin concentration, and they were predictive indexes of type 2 diabetes mellitus (26). However, the roles of ADP and TNF- $\alpha$ in GDM remain unclear. Some studies considered that dysregulation of various adipocyte factors in GDM may have pathophysiological and prognostic significance in pregnancy complications (27). Inflammation is characterized by an increase in the activity of inflammatory circulating biomarkers and monocytes. The association of inflammation and hyperglycemia with insulin resistance has been extensively studied in diabetic patients (28). This investigation was to provide relevant basis for screening and prediction of GDM by studying the changes of ADP and TNF- $\alpha$ concentrations in the blood of GDM patients, and their relationship with pregnancy outcome. In this study, the controls were all healthy pregnant women without gestational diabetes during pregnancy. The results revealed that compared 
Table VI. Association of TNF- $\alpha$ with clinical pathology in the experimental group.

\begin{tabular}{|c|c|c|c|c|}
\hline Clinicopathological characteristics & $\mathrm{n}$ & Concentration (ng/l) & $\mathrm{t}$ value & P-value \\
\hline Age, weeks & & & 2.004 & 0.049 \\
\hline$>28$ & 43 & $6.88 \pm 1.72$ & & \\
\hline$\leq 28$ & 35 & $6.04 \pm 1.98$ & & \\
\hline Pregestational BMI, $\mathrm{kg} / \mathrm{m}^{2}$ & & & 2.074 & 0.041 \\
\hline$\leq 22.15$ & 49 & $6.24 \pm 1.85$ & & \\
\hline$>22.15$ & 29 & $7.25 \pm 2.42$ & & \\
\hline Gestational week & & & 2.411 & 0.018 \\
\hline$\leq 20.23$ & 30 & $5.54 \pm 1.61$ & & \\
\hline$>20.23$ & 48 & $6.71 \pm 2.33$ & & \\
\hline Amniotic fluid volume, $\mathrm{ml}$ & & & 2.083 & 0.041 \\
\hline$\geq 2,000$ & 14 & $7.39 \pm 2.36$ & & \\
\hline$<2,000$ & 64 & $6.14 \pm 1.96$ & & \\
\hline Abortion history & & & 2.460 & 0.016 \\
\hline Yes & 28 & $6.24 \pm 1.72$ & & \\
\hline None & 50 & $5.36 \pm 1.39$ & & \\
\hline Medical history & & & 2.336 & 0.022 \\
\hline Yes & 13 & $6.73 \pm 2.31$ & & \\
\hline No & 65 & $5.44 \pm 1.71$ & & \\
\hline Family history of diabetes mellitus & & & 2.221 & 0.029 \\
\hline Yes & 31 & $6.47 \pm 2.27$ & & \\
\hline None & 47 & $5.42 \pm 1.88$ & & \\
\hline Ethnicity & & & 1.375 & 0.173 \\
\hline Han & 62 & $6.48 \pm 2.11$ & & \\
\hline Minority & 16 & $5.72 \pm 1.26$ & & \\
\hline Dietary habit & & & 0.963 & 0.338 \\
\hline Light & 52 & $5.48 \pm 1.91$ & & \\
\hline Spicy & 26 & $5.89 \pm 1.45$ & & \\
\hline
\end{tabular}

TNF- $\alpha$, tumor necrosis factor- $\alpha$.

with healthy pregnant women, GDM patients showed higher blood TNF- $\alpha$ expression and lower blood ADP expression, which was consistent with previous research results $(29,30)$. The low expression of ADP was related to age, pregestational BMI, gestational week, medical history, and family history of diabetes mellitus (all $\mathrm{P}<0.05$ ), and the high expression of TNF- $\alpha$ was related to age, pregestational BMI, gestational week, amniotic fluid volume, medical history, abortion history, and family history of diabetes mellitus (all $\mathrm{P}<0.05)$. After treatment, the GDM patients showed increased ADP concentration and decreased TNF- $\alpha$ concentration. The study also found that the rate of adverse pregnancy outcomes in the low ADP expression group was higher than that in the high ADP expression group $(\mathrm{P}<0.05)$, and the rate in the high $\mathrm{TNF}-\alpha$ expression group was higher than that in the low TNF- $\alpha$ expression group $(\mathrm{P}<0.05)$. In addition, the risk of adverse pregnancy outcomes in the experimental group was higher than that in the control group. In the present study, GDM patients showed decreased ADP concentration and increased TNF- $\alpha$ concentration, and indexes of delivery were improved after treatment, suggesting that ADP and TNF- $\alpha$ were bound up with GDM. However, whether the pregnancy outcomes can be improved by interfering with ADP and TNF- $\alpha$ expression, and whether there are the same inflammatory factors or adipocyte factors involved in the occurrence of the disease need further study.

However, no basic research was carried out, so it was impossible to assess how ADP and TNF- $\alpha$ participate in the occurrence of diseases or to judge which treatment method can better affect the expression of ADP and TNF- $\alpha$. These aspects require further research, together with the long-term effects of ADP and TNF- $\alpha$ on puerperae and infants.

In conclusion, both ADP and TNF- $\alpha$ are abnormally expressed in the GDM patients, and TNF- $\alpha$ is affected by more of the factors. The concentrations of both ADP and TNF- $\alpha$ affect the pregnancy outcomes. It suggests that ADP and TNF- $\alpha$ can be used as indexes for predicating pregnancy outcomes, and for judging the disease conditions and treatment situation of patients.

\section{Acknowledgements}

Not applicable. 


\section{Funding}

No funding was received.

\section{Availability of data and materials}

The datasets used and/or analyzed during the current study are available from the corresponding author on reasonable request.

\section{Authors' contributions}

WW wrote the manuscript. WW and XZ conceived and designed the study. WW and $\mathrm{XZ}$ were responsible for the collection and analysis of the experimental data. $\mathrm{XZ}$ revised the manuscript critically for important intellectual content. Both authors read and approved the final manuscript.

\section{Ethics approval and consent to participate}

The study was approved by the Ethics Committee of Qingpu Branch of Zhongshan Hospital Affiliated to Fudan University (Shanghai ,China). Patients who participated in this research had complete clinical data. Signed informed consents were obtained from the patients and/or guardians.

\section{Patient consent for publication}

Not applicable.

\section{Competing interests}

The authors declare that they have no competing interests.

\section{References}

1. Pantham P, Aye IL and Powell TL: Inflammation in maternal obesity and gestational diabetes mellitus. Placenta 36: 709-715, 2015.

2. Kampmann U, Madsen LR, Skajaa GO, Iversen DS, Moeller N and Ovesen P: Gestational diabetes: A clinical update. World J Diabetes 6: 1065-1072, 2015.

3. Zhu Y and Zhang C: Prevalence of gestational diabetes and risk of progression to type 2 diabetes: A Global Perspective. Curr Diab Rep 16: 7, 2016.

4. Yu L, Zeng XL, Cheng ML, Yang GZ, Wang B, Xiao ZW, Luo X, Zhang BF, Xiao DW, Zhang S, et al: Quantitative assessment of the effect of pre-gestational diabetes and risk of adverse maternal, perinatal and neonatal outcomes. Oncotarget 8: 61048-61056, 2017.

5. Ainuddin J, Karim N, Hasan AA and Naqvi SA: Metformin versus insulin treatment in gestational diabetes in pregnancy in a developing country: A randomized control trial. Diabetes Res Clin Pract 107: 290-299, 2015.

6. Chiefari E, Arcidiacono B, Foti D and Brunetti A: Gestational diabetes mellitus: An updated overview. J Endocrinol Invest 40: 899-909, 2017.

7. Zhang J, Chi H, Xiao H, Tian X, Wang Y, Yun X and Xu Y: Interleukin-6 (IL-6) and tumor necrosis factor- $\alpha$ (TNF- $\alpha$ ) single nucleotide polymorphisms (SNPs), inflammation and metabolism in gestational diabetes mellitus in Inner Mongolia. Med Sci Monit 23: 4149-4157, 2017.

8. da Costa RM, Neves KB, Mestriner FL, Louzada-Junior P, Bruder-Nascimento T and Tostes RC: TNF- $\alpha$ induces vascular insulin resistance via positive modulation of PTEN and decreased Akt/eNOS/NO signaling in high fat diet-fed mice. Cardiovasc Diabetol 15: 119, 2016.
9. Chen L, Chen R, Wang H and Liang F: Mechanisms linking inflammation to insulin resistance. Int J Endocrinol 2015: $508409,2015$.

10. El-Tahan RR, Ghoneim AM and El-Mashad N: TNF- $\alpha$ gene polymorphisms and expression. Springerplus 5: 1508, 2016.

11. Akash MSH, Rehman K and Liaqat A: Tumor necrosis factor-alpha: Role in development of insulin resistance and pathogenesis of type 2 diabetes mellitus. J Cell Biochem 119: 105-110, 2018.

12. Kadowaki T, Yamauchi T, Kubota N, Hara K, Ueki K and Tobe K: Adiponectin and adiponectin receptors in insulin resistance, diabetes, and the metabolic syndrome. J Clin Invest 116: 1784-1792, 2006.

13. Kc K, Shakya S and Zhang H: Gestational diabetes mellitus and macrosomia: A literature review. Ann Nutr Metab 66 (Suppl 2): 14-20, 2015.

14. Billionnet C, Mitanchez D, Weill A, Nizard J, Alla F, Hartemann A and Jacqueminet S: Gestational diabetes and adverse perinatal outcomes from 716,152 births in France in 2012. Diabetologia 60: 636-644, 2017.

15. Lowe WL Jr, Scholtens DM, Lowe LP, Kuang A, Nodzenski M, Talbot O, Catalano PM, Linder B, Brickman WJ, Clayton P, et al; HAPO Follow-up Study Cooperative Research Group: Association of gestational diabetes with maternal disorders of glucose metabolism and childhood adiposity. JAMA 320: 1005-1016, 2018.

16. Macaulay S, Dunger DB and Norris SA: Gestational diabetes mellitus in Africa: A systematic review. PLoS One 9: e97871, 2014.

17. Kessous R, Shoham-Vardi I,Pariente G, Sherf M and Sheiner E: An association between gestational diabetes mellitus and long-term maternal cardiovascular morbidity. Heart 99: 1118-1121, 2013.

18. Gabbe SG,Landon MB, Warren-Boulton E and Fradkin J: Promoting health after gestational diabetes: A National Diabetes Education Program call to action. Obstet Gynecol 119: 171-176, 2012.

19. Damm P, Houshmand-Oeregaard A, Kelstrup L, Lauenborg J, Mathiesen ER and Clausen TD: Gestational diabetes mellitus and long-term consequences for mother and offspring: A view from Denmark. Diabetologia 59: 1396-1399, 2016.

20. Brown J, Alwan NA, West J, Brown S, McKinlay CJ, Farrar D and Crowther CA: Lifestyle interventions for the treatment of women with gestational diabetes. Cochrane Database Syst Rev 5: CD011970, 2017

21. Nachum Z, Zafran N, Salim R, Hissin N, Hasanein J, Gam ZE Letova Y, Suleiman A and Yefet E: Glyburide versus metformin and their combination for the treatment of gestational diabetes mellitus: A randomized controlled study. Diabetes Care 40: 332-337, 2017.

22. Brown J, Grzeskowiak L, Williamson K, Downie MR and Crowther CA: Insulin for the treatment of women with gestational diabetes. Cochrane Database Syst Rev 11: CD012037, 2017.

23. Feng H, Su R, Song Y, Wang C, Lin L, Ma J and Yang H: Positive correlation between enhanced expression of TLR4/MyD88/NF- $\mathrm{BB}$ with insulin resistance in placentae of gestational diabetes mellitus. PLoS One 11: e0157185, 2016.

24. Lekva T, Michelsen AE, Aukrust P, Henriksen T, Bollerslev J and Ueland T: Leptin and adiponectin as predictors of cardiovascular risk after gestational diabetes mellitus. Cardiovasc Diabetol 16: 5, 2017.

25. Li W, Yang X, Zheng T, Xing S, Wu Y, Bian F, Wu G, Li Y, Li J, Bai X, et al: TNF- $\alpha$ stimulates endothelial palmitic acid transcytosis and promotes insulin resistance. Sci Rep 7: 44659, 2017.

26. Liu C, Feng X, Li Q, Wang Y, Li Q and Hua M: Adiponectin, TNF- $\alpha$ and inflammatory cytokines and risk of type 2 diabetes: A systematic review and meta-analysis. Cytokine 86: 100-109, 2016.

27. Miehle K, Stepan H and Fasshauer M: Leptin, adiponectin and other adipokines in gestational diabetes mellitus and pre-eclampsia. Clin Endocrinol (Oxf) 76: 2-11, 2012.

28. Xie BG, Jin S and Zhu WJ: Expression of toll-like receptor 4 in maternal monocytes of patients with gestational diabetes mellitus. Exp Ther Med 7: 236-240, 2014.

29. Sudharshana Murthy KA, Bhandiwada A, Chandan SL, Gowda SL and Sindhusree G: Evaluation of oxidative stress and proinflammatory cytokines in gestational diabetes mellitus and their correlation with pregnancy outcome. Indian J Endocrinol Metab 22: 79-84, 2018.

30. Çetin C, Baş F, Uçar A, Poyrazoğlu S, Saka N, Bundak R and Darendeliler F: Comparative analysis of glucoinsulinemic markers and proinflammatory cytokines in prepubertal children born large-versus appropriate-for gestational age. Endocrine 47: 816-824, 2014 